\title{
Thermodynamic Constants for Association of Isomeric Chlorobenzoic and Toluic Acids With 1,3-Diphenyl- guanidine in Benzene ${ }^{1}$
}

\author{
Marion Maclean Davis and Hannah B. Hetzer
}

(January 16, 1961)

\begin{abstract}
This paper reports values of $\Delta F_{25}, \Delta H$, and $\Delta S_{25}$ for the association of diphenylguanidine with the isomeric monochlorobenzoic acids and the isomeric toluic acids in benzene from spectrophotometric measurements at 25 and $30{ }^{\circ} \mathrm{C}$, using bromophthalein magenta $\mathrm{E}$ $\left(3^{\prime}, 5^{\prime}, 3^{\prime \prime}, 5^{\prime \prime}\right.$-tetrabromophenolphthalein ethyl ester) as the indicator. The results are compared with available data for other donor-acceptor associations in aprotic solvents which include the monomer-dimer equilibrium of benzoic acids, the association of tertiary amines with iodine, and the association of certain oxygen bases with phenols. The comparisons indicate that the value of the ratio $\Delta H / 298 \Delta S$ is approximately constant in the following associations in aprotic solvents: (1) Association of phenolic or carboxylic acids with nitrogenous bases to form hydrogen bonded ion-pairs; (2) hydrogen bonding of weakly acidic phenols to nitrogenous bases; (3) association of tertiary amines with iodine. A somewhat smaller value for this ratio seems to apply to most associations of phenols with oxygen bases. Possible applications of these findings include estimation of other thermodynamic constants when one of the constants $\Delta F, \Delta H$, or $\Delta S$ is known, and clarification of the relative importance of ionic and covalent contributions in hydrogen bond formation.
\end{abstract}

\section{Introduction}

A spectrophotometric procedure was described earlier [1], ${ }^{2}$ by means of which the relative strengths of 40 carboxylic acids of the benzoic acid series were determined when in benzene solution at $25^{\circ} \mathrm{C}$. The strengths were expressed as values of $K_{a s s o c}$. or log $K_{a s s o c}$. for the reaction

$$
\mathrm{B} \text { (base) }+\mathrm{HA} \text { (acid) } \rightleftarrows \mathrm{BH}^{+} . . \mathrm{A}^{-} \text {, }
$$

in which the base used was 1,3-diphenylguanidine. The phenolic acid, bromophthalein magenta $\mathrm{E}$ $\left(3^{\prime}, 5^{\prime}, 3^{\prime \prime}, 5^{\prime \prime}\right.$ - tetrabromophenolphthalein ethyl ester) served as the indicator dye. An essential step was determining $K$ for the association of diphenylguanidine with bromophthalein magenta E. After completion of the experimental work at $25{ }^{\circ} \mathrm{C}$ [1], analogous measurements at $30{ }^{\circ} \mathrm{C}$ were made for part of these acids, namely, bromophthalein magenta $\mathrm{E}$, benzoic acid, the isomeric chlorobenzoic acids, and the isomeric toluic acids. This paper reports thermodynamic constants derived from the combined data at 25 and $30^{\circ} \mathrm{C}$, and discusses their significance.

\section{Experimental Procedure and Results}

Among the possible sources of error in studies of acid-base equilibria in benzene by spectrophotometry are the volatility of the solvent and effects of adventi-

1 This research was supported in part by the United States Air Force, through the Air Force Office of Scientific Research of the Air Research and Development Command, under contract No. CSO-670-55-21.

2 Figures in brackets indicate the literature references at the end of this paper. tious moisture or oxygen. Such errors can be minimized by making absorbance measurements very soon after the preparation of solutions. ${ }^{3}$ To facilitate speed in obtaining optical data, as well as to reduce errors arising from imprecise temperature control, the temperature in our laboratory is automatically controlled to match closely the temperature within the thermostated air bath which serves as the absorption cell compartment [3]. Throughout most of the year, a laboratory temperature of $25 \pm 0.5^{\circ} \mathrm{C}$ can be maintained. During summer and winter weather, respectively, the laboratory temperature can be held as high as $30^{\circ} \mathrm{C}$ or as low as $20^{\circ} \mathrm{C}$.

Qualitative observations of thermal effects on the extent of association of bromophthalein magenta $\mathrm{E}$ with bases [4] had made it seem likely that enthalpy and entropy changes involved in the kinds of acidbase associations which have been under study could be estimated from optical measurements covering the temperature range 20 to $30{ }^{\circ} \mathrm{C}$, and plans were made to extend the measurements already made at $25{ }^{\circ} \mathrm{C}[1]$ to these two additional temperatures. In August and September of 1955 some of the experiments (see introduction) were repeated at $30^{\circ} \mathrm{C}$, using the same materials and following the same experimental technique as at $25^{\circ} \mathrm{C}$, but the work had to be interrupted without performance of the intended measurements at $20^{\circ} \mathrm{C}$.

The combined results of the experiments at 25 and $30{ }^{\circ} \mathrm{C}$ are summarized in table $1 .{ }^{4}$ The steps

\footnotetext{
3 For example, leakage of atmospheric oxygen into glass-stoppered absorption cells example, leakage of atmospheric oxygen into golution was found to cause cells containing the base tribenzylamine in benzene solution was found to cause its partial conversion to tribenzylamine oxide. To determine the equilibrium constant for association of tribenzylamine with bromophthalein magenta E, the
benzene was freshly boiled to remove dissolved air and the measurements were benzene was freshly boiled to remove dissolved air and the measurements were

4 The raw data reported for $25{ }^{\circ} \mathrm{C}[1]$ are typical of those obtained at $30^{\circ} \mathrm{C}$
} 
followed in calculating association constants corresponding to eq (1), and then applying a correction for the amount of carboxylic acid dimer presumed to be present, were the same as previously explained [1]. As noted in table 1, parallel studies of the association of diphenylguanidine with bromophthalein magenta $\mathrm{E}$ and with benzoic acid at 25 and 30 ${ }^{\circ} \mathrm{C}$ have been made in this laboratory [5], with very similar results.

The dimer-monomer data used in making the corrections are not known with certainty to be accurate. Self-association of diphenylguanidine, formation of complex anions (RCOOHOCOR)-, the "secondary" reaction of diphenylguanidine with bromophthalein magenta E [6], and adsorption of solutes on glass- or silicaware are additional possible causes of errors. However, it is believed that experimental uncertainties in the optical data are the main obstacle to the attainment of high accuracy; these have more effect when the association constants are relatively great in magnitude $\left(10^{5}\right.$ to $\left.10^{6}\right)$, as in the present work. ${ }^{5}$

Values for the thermodynamic constants $\Delta F_{25}$, $\Delta H$, and $\Delta S_{25}$ were calculated in the conventional way from the $K_{\text {assoc }}$. values at the two temperatures.

${ }^{5}$ See [5], footnote 10.
These results are summarized in table $2 .{ }^{6}$

TABLE 2. Thermodynamic constants for association of acids with 1,3-diphenylguanidine in benzene ${ }^{\text {a }}$

\begin{tabular}{|c|c|c|c|c|}
\hline Acid & $\Delta F_{25}$ & $\Delta H$ & $\Delta S_{25}$ & $\frac{\Delta H}{298 \Delta S_{25}}$ \\
\hline Bromophthalein magenta $\mathrm{E}_{\ldots+\ldots}$ & $\begin{array}{c}\text { kcal } \\
\text { mole } e^{-1} \\
-7.38\end{array}$ & $\begin{array}{l}\text { kcal } \\
\text { mole } \\
-15.8\end{array}$ & $\begin{array}{l}c a l \\
\text { mole-1 } \\
\operatorname{deg}^{-1} \\
-28.2\end{array}$ & 1.9 \\
\hline Benzoic_..- & -7.24 & -16.2 & -30.1 & 1. 8 \\
\hline $\begin{array}{l}o \text {-Chlorobenzoic } \\
m \text {-Chlorobenzoic- } \\
p \text {-Chlorobenzoic- }\end{array}$ & $\begin{array}{l}-8.32 \\
-8.30 \\
-7.97\end{array}$ & $\begin{array}{l}-18.8 \\
-19.0 \\
-18.0\end{array}$ & $\begin{array}{l}-35.1 \\
-36.0 \\
-33.7\end{array}$ & $\begin{array}{l}1.8 \\
1.8 \\
1.8\end{array}$ \\
\hline $\begin{array}{l}o \text {-Toluic } \\
m \text {-Toluic } \\
p \text {-Toluic_._- }\end{array}$ & $\begin{array}{l}-6.78 \\
-7.06 \\
-7.00\end{array}$ & $\begin{array}{l}-16.5 \\
-16.5 \\
-16.0\end{array}$ & $\begin{array}{l}-32.5 \\
-31.5 \\
-30.1\end{array}$ & $\begin{array}{l}1.7 \\
1.8 \\
1.8\end{array}$ \\
\hline
\end{tabular}

s Calculated from association constants expressed in liter mole $\mathrm{e}^{-1}$ units. See discussion in section 2 of the text.

${ }^{6}$ The values of $\Delta H$ and $\Delta S_{25}$ given in table II of [5] for the association of diphenylguanidine with bromophthalein magenta $\mathrm{E}$ and benzoic acid were based on

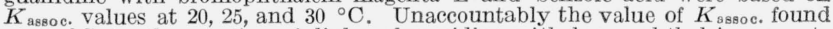
at $20{ }^{\circ} \mathrm{C}$ for the reaction of diphenylguanidine with bromophthalein magenta was lower than the value expected $\left(\sim 4 \times 10^{5}\right)$ and, as a result, the value of $K$ for the reaction of diphenylguanidine with benzoic acid was also lower than expected. If $4 \times 10^{5}$ is assumed to be approximately the correct $K$ value for the expetion of diphenylguanidine with bromophthalein magenta at $20{ }^{\circ} \mathrm{C}, K$ the association of diphenylguanidine with bios the expected magnitude, ond $K$ thermodynamic constants obtained agree closely with the ones given in table 2 of this paper.

$\mathrm{T}_{\mathrm{ABLE}}$ 1. Equilibrium constants for association of acids with 1,3-diphenylguanidine in benzene at 25 and $30{ }^{\circ} \mathrm{C}$

\begin{tabular}{|c|c|c|c|c|c|c|c|c|}
\hline Acid & $\mathrm{t}\left({ }^{\circ} \mathrm{C}\right)$ & No. expts. & Range of $n^{\mathrm{a}}$ & Range of $n^{\prime \prime}$ a & $10^{3} K_{21}{ }^{\mathrm{b}}$ & $10^{-5} K_{\text {cor. }}{ }^{b}$ & St.' dev. & $\begin{array}{l}\text { Coeff. } \\
\text { var. } \%\end{array}$ \\
\hline \multirow{2}{*}{$\begin{array}{l}\text { Bromophthalein } \\
\text { magenta E }\end{array}$} & 25 & 10 & 0.25 to 3 & & & $\begin{array}{l}2.55 \\
2.57^{\mathrm{e}}\end{array}$ & 0. 098 & 3.8 \\
\hline & 30 & 8 & .75 to 3 & & & $\begin{array}{l}\text { 1. } 64 \\
\text { 1. } 66^{\mathrm{e}}\end{array}$ & .070 & 4. 3 \\
\hline \multirow{2}{*}{ Benzoic $\ldots \ldots$} & 25 & 25 & 1 to 3 & 0.5 to 5 & 1. 6 & $\begin{array}{l}\text { 2. } 01 \\
\text { 2. } 09^{\mathrm{c}}\end{array}$ & .045 & 2. 2 \\
\hline & 30 & 8 & 0.5 to 3 & .5 to 3 & 2. 0 & $\begin{array}{l}\text { 1. } 28 \\
\text { 1. } 31^{\mathrm{e}}\end{array}$ & 081 & 6.3 \\
\hline o-Chlorobenzoic_....... & $\left\{\begin{array}{l}25 \\
30\end{array}\right.$ & $\begin{array}{l}9 \\
8\end{array}$ & $\begin{array}{l}.5 \text { to } 3 \\
.5 \text { to } 3\end{array}$ & $\begin{array}{l}.5 \text { to } 4 \\
.5 \text { to } 4\end{array}$ & $\begin{array}{l}\text { 3. } 7 \\
4.7\end{array}$ & $\begin{aligned} & 12.5 \\
7 . & 42\end{aligned}$ & $\begin{array}{l}.047 \\
.235\end{array}$ & $\begin{array}{l}\text { 3. } 8 \\
\text { 3. } 2\end{array}$ \\
\hline$m$-Chlorobenzoic....... & $\left\{\begin{array}{l}25 \\
30\end{array}\right.$ & $\begin{array}{r}16 \\
8\end{array}$ & $\begin{array}{l}.5 \text { to } 3 \\
.5 \text { to } 3\end{array}$ & $\begin{array}{l}.5 \text { to } 5 \\
.5 \text { to } 4\end{array}$ & $\begin{array}{l}\text { 2. } 4 \\
\text { 3. } 0\end{array}$ & $\begin{array}{r}\text { 12. } 1 \\
\text { 7. } 13\end{array}$ & $\begin{array}{l}023 \\
.116\end{array}$ & $\begin{array}{l}\text { 1. } 9 \\
\text { 1. } 6\end{array}$ \\
\hline$p$-Chlorobenzoic ...... & $\left\{\begin{array}{l}25 \\
30\end{array}\right.$ & $\begin{array}{l}8 \\
9\end{array}$ & $\begin{array}{l}.5 \text { to } 3 \\
.5 \text { to } 3\end{array}$ & $\begin{array}{l}.5 \text { to } 4 \\
.5 \text { to } 4\end{array}$ & $\begin{array}{l}(1.7) \\
(2.0)\end{array}$ & $\begin{array}{l}\text { 6. } 94 \\
\text { 4. } 20\end{array}$ & $\begin{array}{l}133 \\
.108\end{array}$ & $\begin{array}{l}\text { 1. } 9 \\
\text { 2. } 6\end{array}$ \\
\hline o-Toluic . . ...... & $\left\{\begin{array}{l}25 \\
30\end{array}\right.$ & $\begin{array}{r}19 \\
8\end{array}$ & $\begin{array}{l}5 \text { to } 3 \\
1 \text { to } 3\end{array}$ & $\begin{array}{r}5 \text { to } 8 \\
.25 \text { to } 4\end{array}$ & $\begin{array}{l}\text { 2. } 4 \\
\text { 3. } 0\end{array}$ & $\begin{array}{r}0.930 \\
.588\end{array}$ & $\begin{array}{l}179 \\
.112\end{array}$ & $\begin{array}{l}\text { 1. } 9 \\
\text { 1. } 9\end{array}$ \\
\hline$m$-Toluic - & $\left\{\begin{array}{l}25 \\
30\end{array}\right.$ & $\begin{array}{r}11 \\
9\end{array}$ & $\begin{array}{r}1 \text { to } 3 \\
0.5 \text { to } 3\end{array}$ & $\begin{array}{r}1 \text { to } 8 \\
0.5 \text { to } 4\end{array}$ & $\begin{array}{l}\text { 1. } 4 \\
\text { 1. } 8\end{array}$ & $\begin{array}{l}\text { 1. } 50 \\
0.948\end{array}$ & $\begin{array}{l}041 \\
.219\end{array}$ & $\begin{array}{l}\text { 2. } 7 \\
\text { 2. } 3\end{array}$ \\
\hline$p$-Toluic _. & $\left\{\begin{array}{l}25 \\
30\end{array}\right.$ & $\begin{array}{r}10 \\
6\end{array}$ & $\begin{array}{r}1 \text { to } 3 \\
0.5 \text { to } 3\end{array}$ & $\begin{array}{r}1 \text { to } 4 \\
0.5 \text { to } 3\end{array}$ & $\begin{array}{l}0.415 \\
0.53\end{array}$ & $\begin{array}{l}\text { 1. } 34 \\
0.859\end{array}$ & $\begin{array}{l}.084 \\
.288\end{array}$ & $\begin{array}{l}6.3 \\
3.4\end{array}$ \\
\hline
\end{tabular}

a The molar concentration $\left(\mathrm{C}_{\mathrm{a}}\right)$ of bromophthalein magenta $\mathrm{E} ; 3^{\prime}, 5^{\prime}, 3^{\prime \prime}, 5^{\prime \prime}$-tetrabromophenolphthalein ethyl ester) was $5.0 \times 10^{-5}$ throughout. The molar concentrations of 1,3 -diphenylguanidine $\left(n \mathrm{C}_{\mathrm{a}}\right)$ and of the aromatic carboxylic acid $\left(n^{\prime \prime} \mathrm{C}_{\mathrm{a}}\right)$ varied within the ranges indicated. Experimental procedure and apparatus were as described in [1].

b $K_{21}$ is the equilibrium constant for dissociation of dimeric carboxylic acid into the monomer in benzene, while $K_{\text {cor. }}$ is the equilibrium constant for the association $\mathrm{A}$ (acid) $+\mathrm{B}$ (base) $\leftrightarrows \mathrm{S}$ (salt) in benzene after the raw data have been corrected by taking into consideration the dimer-monomer equilibrium of the carboxylic acid; for method of calculating $K_{\text {cor. }}$ see [1], especially sections 3.2 and 4.1. The values of $K_{21}$ used in correcting the association constants were based on data in the literature except in the cases of $m$ - and $p$-chlorobenzoic acids, for which $K_{21}$ values have not been reported. In the case of $m$-chlorobenzoic acid, data for $m$-iodobenzoic acid were applied; in that of $p$-chlorobenzoic acid, $K_{21}$ values at 25 and $30{ }^{\circ} \mathrm{C}$ were estimated by trial and error. All equilibrium constants given in this table are in molar units.

- Reference [5]. 


\section{Discussion}

Two well-known thermodynamic equations,

$$
-R T \ln K=\Delta F
$$

and

$$
\Delta F=\Delta H-T \Delta S,
$$

are frequently utilized in efforts to develop generalizations about the effects of structural modifications on reaction rates and equilibria (for example, see [7 to 13]). The great majority of the attempts to assess relative contributions of changes in enthalpy and entropy to free energy changes have been made in connection with studies of reaction kinetics. In some instances, a structural change apparently leads to an increase in the energy of activation, with little or no effect on the entropy factor. ${ }^{7}$ In other cases, an increase in the energy of activation is accompanied by a parallel effect on the entropy factor. ${ }^{8}$

A class of chemical equilibria which is of major interest is the ionization of acids of the benzoic acid series in water, since this reaction series was adopted for evaluating substituent constants in the Hammett equation [8]. Thermodynamic constants for the aqueous ionization of some benzoic acids pertinent to this paper are compiled in table 3 . The $\Delta H$ values for these acids, except in the case of 0 toluic acid, are much less than one $\mathrm{kcal} \mathrm{mole}^{-1}$ in magnitude. Clearly, the values of $\Delta F_{25}$ for aqueous ionization of the acids depend almost solely on the temperature-entropy term, $T \Delta \mathrm{S}$.

The thermodynamic constants obtained in this work for association of benzoic acids with 1,3diphenylguanidine in benzene (table 2) contrast greatly with the corresponding constants for aqueous ionization. ${ }^{9}$ Values of $\Delta H$ are in the approximate

TABLE 3. Thermodynamic constants for ionic dissociation of

\begin{tabular}{|c|c|c|c|c|}
\hline Acid & $\Delta \mathrm{F}_{25}$ & $\Delta \mathrm{H}$ & $\Delta \mathrm{S}_{25}$ & $298 \Delta \mathrm{S}_{25}$ \\
\hline Benzoic & $\begin{array}{c}\text { kcal } \\
\text { mole-1 } \\
5.74\end{array}$ & $\begin{array}{c}k c a l \text { mole } e^{-1} \\
0.11^{\text {a } 0.104} \circ 0.09 \mathrm{~d}\end{array}$ & $\begin{array}{c}\text { cal mole } \text { mel }^{-1} \\
\text { deg }^{-1} \\
-18.9^{\mathrm{a}} \mathrm{od}\end{array}$ & $\begin{array}{c}\text { kcal } \\
\text { mole-1 } \\
-5.64\end{array}$ \\
\hline $\begin{array}{l}m \text {-Chlorobenzoic } \\
m \text {-Iodobenzoic } \\
p \text {-Chlorobenzoic }\end{array}$ & $\begin{array}{l}\text { 5. } 22 \\
5.26 \\
5.43\end{array}$ & $\begin{array}{l}.019 \mathrm{~b} \\
.190 \mathrm{~b} \\
.226 \mathrm{~b}\end{array}$ & $\begin{array}{l}-17.4 \mathrm{~b} \\
-17.0 \mathrm{~b} \\
-17.5 \mathrm{~b}\end{array}$ & $\begin{array}{l}-5.19 \\
-5.07 \\
-5.22\end{array}$ \\
\hline $\begin{array}{l}\text { o-Toluic } \\
m \text {-Toluic } \\
p \text {-Toluic_... }\end{array}$ & $\begin{array}{l}\text { 5. } 33 \\
5.78 \\
5.92\end{array}$ & $\begin{array}{l}-1.50 \mathrm{~d} \\
0.07 \mathrm{~b} \mathrm{~d} \\
0.30 \mathrm{~b} \quad 0.24 \mathrm{~d}\end{array}$ & $\begin{array}{l}-22.9 \mathrm{~d} \\
-19.2 \mathrm{bd} \\
-19.0 \mathrm{~d}\end{array}$ & $\begin{array}{l}-6.83 \\
-5.72 \\
-5.67\end{array}$ \\
\hline
\end{tabular}
selected benzoic acids in water

a T. L. Cottrell, G. W. Drake, D. L. Levi, K. J. Tully, and J. H. Wolfenden, J. Chem. Soc. (London) 1948, 1016

b G. Briegleb and A. Bieber, Z. Elektrochem. 55, 250 (1951)

c A. V. Jones and H. N. Parton, Trans. Faraday Soc. 48, 8 (1952).

c A. V. Jones and H. N. Parton, Trans. Faraday Soc. 48, 8 (1952). 1743 (1959).

7 For example, in the alkaline hydrolysis of $m$-and $p$-substituted ethyl benzoates in 85-percent aqueous ethanol [14].

8 An illustration is the acidic hydrolysis of $m$ - and $p$-substituted ethyl benzoates in 85-percent aqueous ethanol [15].

85 -percent aqueous ethanol
In comparing relative acidic strengths in water and benzene, one must bear in mind that the primary acid-base reaction eq (1) is a shift of the acid proton toward mind that the primary acid-base reaction eq (1) is a shift of the acid proton toward the base to form hydrogen-bonded ion-pairs. Formation of independently moving ions occurs to a very minor extent unless the ions can become hydrogenbonded to molecules of solvent or solute $[3,6]$. This "
likely to hamper study of the main acid-base interaction. range 16 to $19 \mathrm{kcal}$ mole ${ }^{-1}$, are all negative in sign, and the variations in numerical magnitude parallel those in the temperature-entropy term, the ratio $\Delta H / 298 \Delta S_{25}$ being 1.8 , or very close to this value, in all cases. For five of the reactions $\Delta H / \Delta F_{25}$ is 2.3 the extreme values being 2.1 and 2.4 .

For comparison, available values of $\Delta H$ and $\Delta S_{25}$ for the monomer-dimer equilibrium of the same or closely related benzoic acids are presented in table 4. It is of considerable interest that the ratio $\Delta H / 298 \Delta S_{25}$ has practically the same value for the self-association of the benzoic acids in benzene as for their association with diphenylguanidine in this solvent. ${ }^{10}$ The enthalpy-entropy relationship for the two kinds of association reactions is also brought out in figure 1 , in which $-\Delta S_{25}$ is plotted against $-\Delta H$. In this figure the equation for the solid line was calculated by the method of least squares, using data for all seven of the carboxylic acids. ${ }^{11}$ The dashed line is an extension of the solid line. For the monomer-dimer equilibrium, $\Delta H / \Delta F_{25}$ varies from 2.1 to 2.5 , with the exception of $p$-toluic acid where the value is $1.9 .^{12}$

A few additional investigations of thermodynamic properties of acid-base associations in aprotic solvents have been reported. Table 5 is a compilation of most of the published data. Several tentative conclusions may be drawn:

(1) In most associations in which nitrogen is the proton acceptor (electron donor), the value of $\Delta H / 298 \Delta S_{25}$ is not far from $1.8 .^{13}$

TABLE 4. Thermodynamic constants for self-association of

\begin{tabular}{|c|c|c|c|c|}
\hline Acid & $\Delta F_{25}$ & $\Delta H^{\mathrm{d}}$ & $\Delta S_{25} \mathrm{~d}$ & ${\frac{\Delta H}{298 \Delta S_{25}}}^{\mathrm{d}}$ \\
\hline Benzoic_._-_. & $\begin{array}{c}k c a l \\
m o l e^{-1} \\
-3.81\end{array}$ & $\begin{array}{c}k c a l \\
m o l e^{-1} \\
-8.37\end{array}$ & $\begin{array}{c}\text { cal } \\
\text { mole-1 } \\
\text { deg-1 } \\
-15.3\end{array}$ & 1.8 \\
\hline $\begin{array}{l}0 \text {-Chlorobenzoic b } \\
m \text {-Iodobenzoic b }\end{array}$ & $\begin{array}{l}-3.31 \\
-3.57\end{array}$ & $\begin{array}{l}-8.31 \\
-7.65\end{array}$ & $\begin{array}{l}-16.8 \\
-13.7\end{array}$ & $\begin{array}{l}1.7 \\
1.9\end{array}$ \\
\hline $\begin{array}{l}o \text {-Toluie }{ }^{\circ}-\ldots \\
m \text {-Toluic }{ }^{\mathrm{c}} \text {-Toluic } \\
p \text {-To }\end{array}$ & $\begin{array}{l}-3.58 \\
-3.91 \\
-4.61\end{array}$ & $\begin{array}{l}-8.39 \\
-9.26 \\
-8.72\end{array}$ & $\begin{array}{l}-16.1 \\
-17.9 \\
-13.8\end{array}$ & $\begin{array}{l}\text { 1. } 7 \\
1.7 \\
2.1\end{array}$ \\
\hline
\end{tabular}
aromatic acids in benzene a

Calculated from monomer-dimer equilibrium constants $\left(\boldsymbol{K}_{12}\right)$ expressed in liter mole $\mathrm{C}^{-1}$ units.

b Computed from data of G. Allen and E. F. Caldin (ref. [18]), after converting monomer-dimer constants from mole fraction units to liter mole ${ }^{-1}$ units

c From data of F. T. Wall and F. W. Banes, J. Am. Chem. Soc. 67, 898 (1945)

d Dividing these values of $\Delta H$ and $\Delta S_{25}$ by two, so as to obtain the average values per hydrogen bond has no effect, of course, on the ratio $\Delta H / T \Delta S$

10 Others have recognized a linear correlation of $\Delta H$ and $\Delta S$ in the dimerization of carboxylic acids, as well as in some additional instances of hydrogen bond formation $[16,17]$, but the units of concentration were not the same as those used here, thus leading to different values for $\Delta H$ and $\Delta S$.

11 Omitting data for 0 -toluic acid would have given a still better correlation of $\Delta H$ with $\Lambda S_{25}$ values.

${ }_{12} p$-Toluic acid shows anomalous behavior in the comparison of $K_{12}$ values for carboxylic acids in benzene with the $K_{\text {inn }}$. values in water [16]. Its tendency to dimerize in benzene [18] seems surprisingly great.

13 The thermodic systems in cyclohexane The thermodynamic constants for the three base-acid systems in cyciohexane the agreement of two of the values of $\Delta H / 298 \Delta S_{25}$ with those for stronger acid-base interactions is very good. 


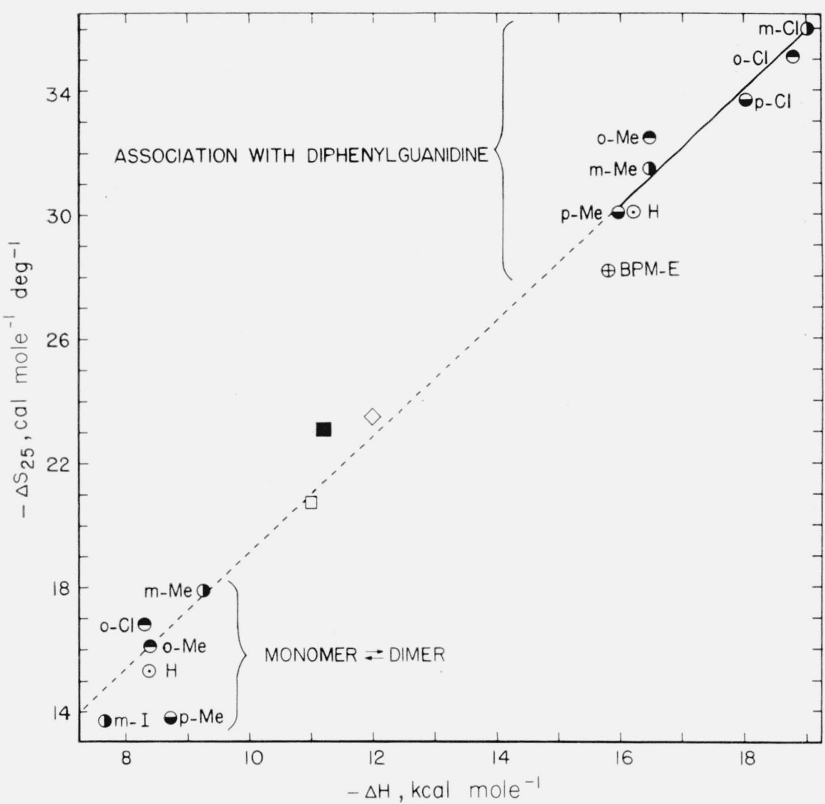

Figure 1. $-\Delta S_{25}$ versus $-\Delta H$ for association of some benzoic acids with 1,3-diphenylguanidine and for self-association (dimerizotion) of the same or analogous acids, in benzene.

$\mathrm{H}$, Benzoic acid; 0 -, $m$-, and $p$-Me, the toluic acids; $0-, m$-, and $p$-Cl, the monochlorobenzoic acids; BPM-E, bromophthalein magenta E; see table 2. The unlabeled symbols refer to the following associations (see table 5): open square, triethylamine with benzoic acid in benzene: filled square, tribenzylamine with picric acid in benzene; open diamond, triethylamine plus iodine in $n$-heptane.
(2) Statement (1) holds irrespective of whether the acid is a Bronsted acid (phenol, carboxylic acid) or the Lewis acid iodine.

(3) In most associations in which oxygen is the proton acceptor (electron donor), the value of $\Delta H / 298 \Delta S_{25}$ is $1.4 .^{14}$ Results with dioxane and methyl or ethyl acetate as the base indicate that the values of both $-\Delta H$ and $-\Delta S_{25}$ increase on changing from carbon tetrachloride to a saturated hydrocarbon solvent, but without affecting the ratio of the two values.

(4) With benzene as base ( $\pi$-electron donor), the value of $\Delta H / 298 \Delta S$ seems to be smaller. ${ }^{15}$

A linear relationship of $-\Delta H$ and $-\Delta S$ in a related series of association reactions has been interpreted as signifying that with increasing strength of the bond between donor and acceptor there is increased restraint on motions of the component parts. ${ }^{16}$ Per-

4 The monomer-dimer equilibrium of benzoic acids (see table 4) does not conform to this generalization.

15 The very interesting thermodynamic data for formation of alkylbenzeneiodine [19] and alkylbenzene-iodine monochloride [20] complexes in carbon tetrachloride solution, which show a linear correlation of $\Delta H$ and $\Delta S$, are in other units of concentration, and raw data necessary for conversion to molar units were not published. Consistent use of molar units of association in presenting thermodynamic properties of such association reactions would have the advantage of facilitating comparisons with systems containing both donor and acceptor compounds in concentrations much too low for use of mole fraction units.

16 For example, see $[17,19,20]$.

TABLE 5. Thermodynamic constants for miscellaneous acid-base associations in aprotic solvents ${ }^{a}$

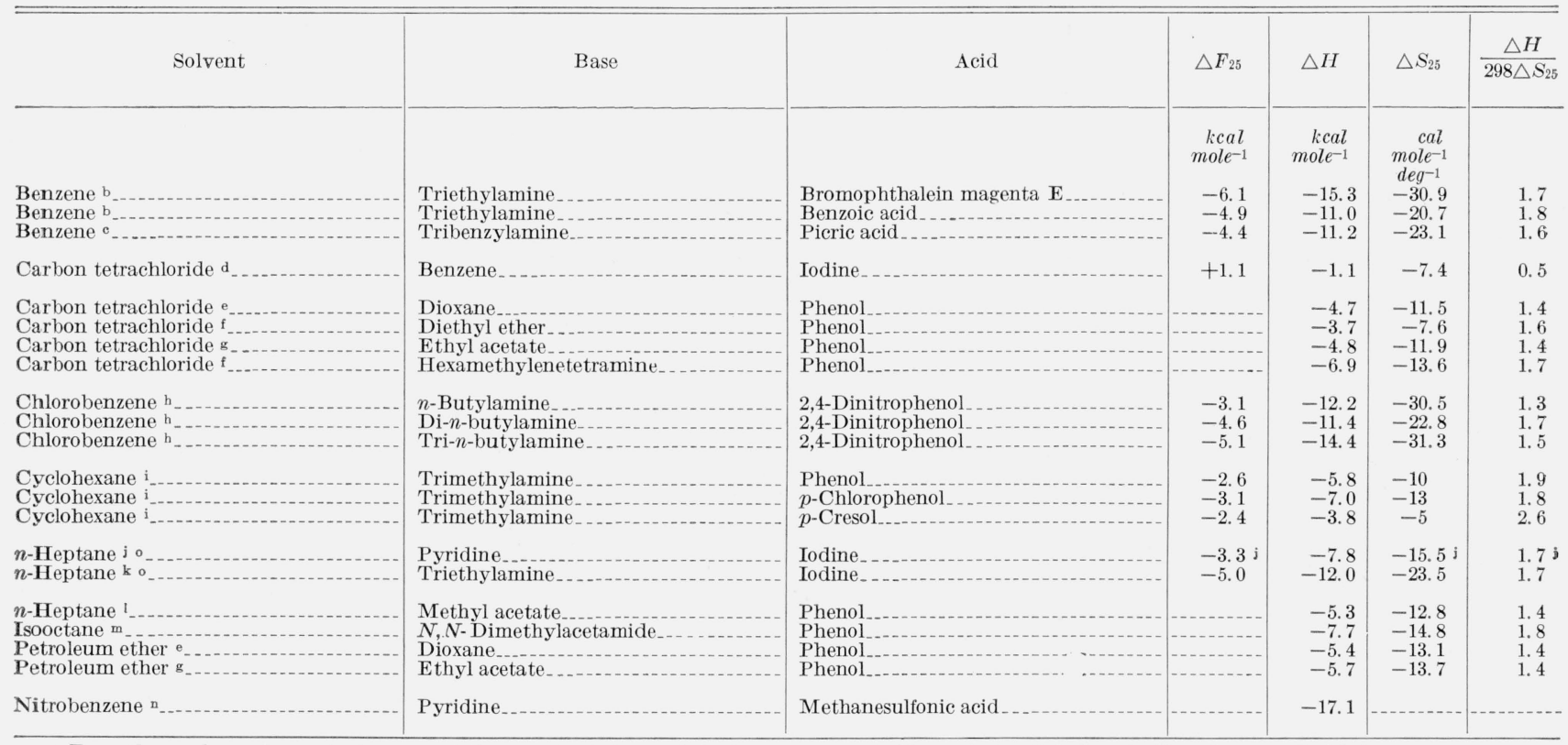

a From thermodynamic constants or association constants (converted where necessary to liter mole ${ }^{-1}$ units) given in the references cited below.

b Reference [5].

- A. A. Maryott, J. Research NBS 41, 7 (1948); M. M. Davis and E. A. McDonald, J. Research NBS 42, 595 (1949).

d See reference [5], table II, footnote $f$.

- S. Nagakura, J. Chem. Soc. Japan, Pure Chem. Sect. 74, 153 (1953), through reference [17], appendix B

i M. Tsuboi, Bull. Chem. Soc. Japan 25, $60(1952)$.

f M. Tsuboi, Bull. Chem. Soc. Japan 25, $60(1952)$
g S. Nagakura, J. Am. Chem. Soc. 76, $3070(1954)$

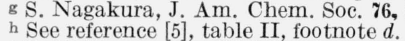

i R. L. Denyer, A. Gilchrist, J. A. Pegg, J. Smith, T. E. Tomlinson, and L. E. Sutton, J. Chem. Soc. (London) 1955, $3889 ;$ see table 5.

j C. Reid and R. S. Mulliken, J. Am. Chem. Soc. $76,3869(1954) . \Delta F$ and $\Delta S$ are for $17{ }^{\circ} \mathrm{C}$ instead of $25^{\circ} \mathrm{C}$.

k S. Nagakura, J. Am. Chem. Soc. 80, $520(1958)$.

1 S. Nagakura, J. Chem. Soc. Japan, Pure Chem. Sect. 75, 734 (1954), through reference [17], appendix B.

$\mathrm{m}$ S. Mizushima, M. Tsuboi, T. Shimanouchi, and Y. Tsuda, Spectrochim. Acta 7, 100 (1955).

n H. C. Brown and R. R. Holmes, J. Am. Chem. Soc. 7 7, 1727 (1955).

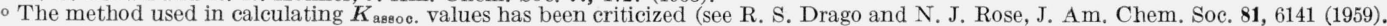


haps the different values which $\Delta H / 298 \Delta S_{25}$ seems to have (see table 5) for bases with nitrogen as the electron donor atom and those with oxygen as the electron donor (approximately 1.8 and 1.4 , respectively) result chiefly from variations in $-\Delta H$.

The existent thermodynamic data for donoracceptor reactions in aprotic solvents are not extensive enough to determine the scope of the relationships indicated above, or accurate enough to detect possible small effects resulting from variations in structure as, for example, isomerism in the toluic acids or the chlorobenzoic acids. Two important areas of possible application may be suggested, however.

(1) If one of the three constants $\Delta F, \Delta H$, and $\Delta S$ is known, it should be possible to estimate values for the other two. To illustrate, from the value of $\Delta H$ which has been determined for association of pyridine with methanesulfonic acid in nitrobenzene (see table 5 ), estimated values for $\Delta S_{25}, \Delta F$, and $K_{\text {assoc. }}$, in the units used above, are $-32,-7.6$, and $3.7 \times 10^{5}$, respectively. The assumption must be made that nitrobenzene does not affect the association differently from other solvents listed in the table. A further example concerns association of triethylamine with phenol in $n$-heptane. The reported value of $K_{\text {assoc. }}$ at $25^{\circ} \mathrm{C}$ is 83.8 [21]. This leads to the following approximate values for $\Delta F, \Delta H$, and $\Delta S_{25}$, respectively: $-2.6,-5.9$, and -11 . These agree well with the constants reported for association of trimethylamine with phenol in cyclohexane (see table 5).

(2) The theory of hydrogen bond formation still needs clarification (see [17], chs. 7 and 8). Evidence for hydrogen bonding in ion-pairs of salts that are formed by union of nitrogenous bases with hydrogen acids (and therefore have one or more protons attached to the nitrogen of the cation) has been pointed out $([4,2,5]$ and references cited), but has not received wide consideration in discussions of hydrogen bonding. The thermodynamic data in tables 2, 4, and 5 point to a relationship of such systems with the more weakly bonded systems which so far have been the basis for speculations about the nature of hydrogen bonding and the relative importance of ionic and covalent contributions.

\section{References}

[1] M. M. Davis and H. B. Hetzer, J. Research NBS 60, 569 (1958) RP2871.

[2] M. M. Davis and H. B. Hetzer, J. Am. Chem. Soc. $\boldsymbol{\gamma 6}$, 4247 (1954).

[3] M. M. Davis and H. B. Hetzer, J. Research NBS 48, 381 (1952) RP2326.

[4] M. M. Davis and P. J. Schuhmann, J. Research NBS 39, 221 (1947) RP1825.

[5] M. M. Davis and M. Paabo, J. Am. Chem. Soc. 82, 5081 (1960).

[6] M. M. Davis and H. B. Hetzer, J. Researeh NBS 46, 496 (1951) RP2219.

[7] A. E. Stearn and H. Eyring, J. Chem. Phys. 5, 113 (1937).

[8] L. P. Hammett, Physical organic chemistry, chs. III and IV (McGraw-Hill Book Co., Inc., New York, N.Y., 1940).

[9] K. F. Laidler and H. Eyring, Ann. N.Y. Acad. Sci. 39, 303 (1940).

[10] C. K. Ingold, Structure and mechanism in organic chemistry, ch. II, 6c and 6d (Cornell University Press, Ithaca, N.Y., 1953).

[11] J. E. Leffler, J. Org. Chem. 20, 1202 (1955)

[12] J. Hine, Physical organic chemistry, chs, 2-4 and 3-3 (McGraw-Hill Book Co., Inc., New York, N.Y., 1956).

[13] R. P. Bell, The proton in chemistry, ch. V (Cornell University Press, Ithaca, N.Y., 1959).

[14] (a) C. K. Ingold and W. S. Nathan, J. Chem. Soc. (London) 1936, 222; (b) D. P. Evans, J. J. Gordon, and H. B. Watson, J. Chem. Soc. (London) 1937, 1430.

[15] E. W. Timm and C. N. Hinshelwood, J. Chem. Soc. (London) 1938, 862.

[16] G. Allen and E. F. Caldin, Quart. Revs. (London) 7 , 255 (1953).

[17] G. C. Pimentel and A. L. McClellan, The hydrogen bond, ch. 7 (W. H. Freeman and Co., San Francisco, Calif., 1960).

[18] G. Allen and E. F. Caldin, Trans. Faraday Soc., 49, 895 (1953).

[19] R. M. Keefer and L. J. Andrews, J. Am. Chem. Soc. 77, $2164(1955)$.

[20] N. Ogimachi, L. J. Andrews, and R. M. Keefer, J. Am. Chem. Soc. 7\%, 4202 (1955).

[21] S. Nagakura and M. Gouterman, J. Chem. Phys. 26, 881 (1957). 